\title{
SERUM FERRITIN STATUS IN MICROCYTIC HYPOCHROMIC ANAEMIC MEDICAL STUDENTS
}

\author{
HAFIZA AKHTER ${ }^{1}$, NASIM JAHAN ${ }^{2}$, NAYMA SULTANA ${ }^{3}$, TABASSUM FERDOUS ${ }^{4}$, HASINA AKHTER ${ }^{5}$, MAFRUHA \\ NAZNEEN ${ }^{6}$
}

${ }^{1}$ Assistant professor, Department of Physiology, Dr. Sirajul Islam Medical College, Dhaka.

${ }^{2}$ Professor and Head, Department of Physiology, Sir Salimullah Medical College, Mitford, Dhaka.

${ }^{3}$ Associate Professor, Department of Physiology, Sir Salimullah Medical College, Mitford, Dhaka.

${ }^{4}$ Assistant Professor, Department of Physiology, Nightingale Medical College, Dhaka.

${ }^{5}$ Assistant Professor, Department of Microbiology, Bangladesh Medical College, Dhaka.

${ }^{6}$ Associate Professor, Department of Biochemistry, Dhaka Central International Medical College, Dhaka.

\begin{abstract}
Background: Microcytic hypochromic anaemia is common in young adults, specially in females. It is important to know the serum ferritin status of the medical students who will be involved, in future, with the health care delivery system and to prevent anaemia among them. Objective: To observe the serum ferritin status in microcytic hypochromic anaemic medical students. Methods: This cross sectional study was carried out in the Department of Physiology, Sir Salimullah Medical College, Dhaka from July 2009 to June 2010. A total number of 516 apparently healthy young adults of both sexes, age ranged from 18 to 22 years, were selected for the study from two medical college in Dhaka city. Of them, 276 were nonanaemic (control group A) and 240 were anaemic (study group B). Again, anaemic (B) subjects are divided into anaemic female $\left(B_{1}\right)$ and anaemic male $\left(B_{2}\right)$. Among the anaemic $(B)$ subjects, 170 had normocytic normochromic , 68 had microcytic hypochromic and 2 had macrocytic hypochromic anaemia. Serum ferritin was estimated by Micro-particle Enzyme Immunoassay in subjects (68 in number) who were suffering from microcytic hypochromic anaemia. The statistical analysis was done by using unpaired 't' test , Pearson's correlation coefficient test as applicable. Result: The mean serum ferritin level was almost similar and showed no statistically significant difference between group $B_{1}$ and $B_{2}$. Again, a significant positive correlation of serum ferritin level with haemoglobin was observed in both female and male in microcytic hypochromic anaemic group. Conclusion: This study reveals that serum ferritin level is one of the most sensitive and accurate indicator indicating iron status and thus microcytic hypochrmic anaemia.
\end{abstract}

Keywords: Serum ferritin, Microcytic hypochromic aneamia, Medical students

(Bangladesh J Physiol Pharmacol 2012;28(1\&2):23-28.)

\section{INTRODUCTION}

The most widespread nutritional problem in the world is anaemia. At least one billion people have been estimated to be anaemic which is $10 \%-20 \%$ of the world population..$^{1,2}$ Iron deficiency anaemia and vitamin A deficiency are probably the most common micronutrient deficiencies in the developing countries. ${ }^{3}$

Iron deficiency anaemia is characterized by a defect in haemoglobin synthesis, resulting in abnormally small sizes of red blood cells (microcytes) containing decreased amount of haemoglobin. ${ }^{4}$

Physiological processes during puberty are particularly linked to increase requirements for iron and zinc to meet the increased demand for erythropoiesis as well as high growth rate. ${ }^{5,6}$ Iron is also an essential

Address for correspondence: Dr. Hafiza Akhter, Assistant professor, Department of Physiology, Dr. Sirajul Islam Medical College, Dhaka. E-mail: akhter.hafiza@yahoo.com Cell No. : 01819262488 nutrient for skeletal growth and iron deficiency may acts as a limiting factor for growth during adolescent. ${ }^{7}$ Iron deficiency anaemia causes limitation in intellectual development in children and impaired work performances in adults which together constrain social and economic development. ${ }^{8,9,10}$ Rapid growth along with fast lifestyle and poor dietary choices can result iron deficiency anaemia. ${ }^{11,12}$ During adolescence, requirement of iron is increased in male for increasing blood volume, muscle mass and myoglobin, whereas in female due to increased demand for growth and loss of iron at the onset of menstruation. ${ }^{13,14,15}$

Serum ferritin considered to be the most sensitive indicator of iron status. ${ }^{16,17}$ Its concentration is usually lower in iron deficiency and low level reflects depleted body iron stores. ${ }^{18}$ The level of serum ferritin below 15 $\mu \mathrm{g} / \mathrm{L}$ is considered to be iron depleted. ${ }^{19}$ 
So, Serum ferritin levels were estimated only in microcytic hypochromic anaemic subjects to find out their satus in anaemia. ${ }^{20}$ The measurement of serum ferritin is useful as it reflects the total iron stores of the body. ${ }^{21}$ Low serum ferritin level in addition to low haemoglobin or haematocrit confirms the diagnosis of iron deficiency anaemia. ${ }^{8,22,11}$

Several studies have been carried out about serum ferritin level among different population groups in Bangladesh but the young adults did not get much attention in those studies. Early adulthood is an important stage of physical and mental development in life. The changes that occur in an individual during this period are accompanied by progressive achievement of biological maturity. Moreover, for female this is the period of preparation for motherhood. Health and nutritional status of female population in this period may have great impact on the quality of the next generation. So, the present study has been designed to observe the serum ferritin status among the urban and educated young adults, age ranged from 18 to 22 years. It is expected that the result of the study would give a base line information regarding microcytic hypochromic anaemia and also be helpful to make a medical health plan for management and prevention of microcytic hypochromic anaemia in young adult.

\section{METHODOLOGY}

This cross sectional study was carried out in the Department of Physiology, Sir Salimullah Medical College, Dhaka, between July 2009 to June 2010. A total number of 516 young adults of both sexes, age ranged from 18 to 22 years, were selected for the study from Sir Salimullah Medical College and Bangladesh Medical College, Dhaka. Their haematological parameters $(\mathrm{Hb}, \mathrm{TC}$ of $\mathrm{RBC}, \mathrm{PCV})$ were done for detection of anaemia. Of them, 276 were nonanaemic (control group A) and 240 were anaemic (Study group B). Group A (control) divided into group $A_{1}$ consists of nonanaemic female and group $A_{2}$ consists of nonanaemic male. Again, Group $B$ is divided into $B_{1}$ consists of anaemic female and $B_{2}$ consists of anaemic male. Among the anaemic (B) subjects, 170 had normocytic normochromic, 68 had microcytic hypochromic and 2 had macrocytic hypochromic anaemia. Serum ferritin was estimated in subjects (68 in number) who were suffering from microcytic hypochromic anaemia to find out their status . Protocol of this study was approved by the Institutional Ethics committee (IEC) of Sir Salimullah Medical college, Dhaka. Subjects having history of chronic illness specially haematological diseases and history of taking drug like haematinics, antibiotic, recent history of taking blood transfusion and blood donation were excluded from study. After selection of the subjects, the objectives and benefits of the study were explained to each subjects and written informed consents were taken from the subjects. Detail personal, marital status, dietary, medical, family, socioeconomic, occupational and drug history of each subject were recorded in a prefixed questionnaire and physical examinations were also done and documented. Height and weight of the subjects were measured for the calculation of BMI. With all aseptic precaution $5 \mathrm{ml}$ of venous blood was drawn from antecubital vein by a disposable plastic syringe. Blood was transferred to an acid washed centrifuged tube then serum was separated by centrifugation at a rate of 3000 r.p.m for 5 minutes and supernatant serum was collected in a labelled eppendroff tube to preserve in a refrigerator for estimation of serum ferritin. All the parametric variables were expressed as mean $\pm S D$ (Standard deviation). The statistical analysis was done by unpaired ' $t$ ' test and Person's correlation test by using "SPSS" program version -15.

\section{RESULTS}

All the values were almost similar and no statistically significant differences of ages and BMI were observed among the groups (Table I).

Table I

Mean $\pm S D$ of Age and BMI in different groups $(n=516)$

\begin{tabular}{l|ccc}
\hline Groups & $\mathbf{n}$ & $\begin{array}{c}\text { Age } \\
\text { (years) }\end{array}$ & $\begin{array}{c}\text { BMI } \\
\mathbf{( k g / \mathbf { m } ^ { 2 } )}\end{array}$ \\
\hline$A_{1}$ & 131 & $20.03 \pm 1.41$ & $22.63 \pm 2.19$ \\
& & $(18-22)$ & $(17.58-28.3)$ \\
$A_{2}$ & 145 & $20.01 \pm 1.38$ & $22.77 \pm 2.03$ \\
& & $(18-22)$ & $(19.11-28.19)$ \\
$B_{1}$ & 135 & $19.92 \pm 1.39$ & $22.59 \pm 2.46$ \\
& & $(18-22)$ & $(16.63-28.19)$ \\
$B_{2}$ & 105 & $19.70 \pm 1.32$ & $22.83 \pm 2.58$ \\
& & $(18-22)$ & $(16.63-28.13)$ \\
\hline
\end{tabular}


Results are expressed as Mean \pm SD. Statistical analysis was done by unpaired " $t$ " test. Figure in parentheses indicate ranges.

Control group

Group $A_{1}=$ Non anaemic female Study group

Group $A_{2}=$ Non anaemic male

Group $B_{1}=$ Anaemic female

Group $B_{2}=$ Anaemic male

$\mathrm{n}=$ Number of subjects.

The mean $\mathrm{Hb}$ and PCV levels of the subjects were significantly $(p<0.001)$ higher in nonanaemic male (group $A_{2}$ ) and anaemic male (group $B_{2}$ ) in comparison to those of nonanaemic female (group $A_{1}$ ) and anaemic female ( group $B_{1}$ respectively. Again, these levels were significantly $(p<0.001)$ higher in nonanaemic female and male (group $A_{1}$ and $A_{2}$ ) than those of anaemic female and male (group $B_{1}$ and $B_{2}$ ) respectively. Moreover, mean Total count of RBC of the subjects were higher in nonanaemic male and anaemic male (group $A_{2}$ and $B_{2}$ ) when compared to those of nonanaemic female and anaemic female ( group $A_{1}$ and $B_{1}$ ) respectively. However, the differences were statistically significant $(p<0.001)$ between nonanaemic female vs male $\left(A_{1}\right.$ vs $\left.A_{2}\right)$ whereas non significant between anaemic female vs male $\left(B_{1}\right.$ vs $\left.B_{2}\right)$. Again, this RBC count were significantly $(p<0.001)$ higher in nonanaemic female and male $\left(A_{1}\right.$ and $\left.A_{2}\right)$ than those of anaemic female and male $\left(B_{1}\right.$ and $\left.B_{2}\right)$ respectively.

(Table II)

Table II

Hemoglobin (Hb), PCV and TC of RBC in different groups ( $n=516)$

\begin{tabular}{|c|c|c|c|c|}
\hline Groups & $\mathbf{n}$ & $\begin{array}{c}\text { Hb } \\
(g / d l)\end{array}$ & $\begin{array}{l}\text { PCV } \\
(\%)\end{array}$ & $\begin{array}{c}\text { TC of RBC } \\
\text { (million/cumm) }\end{array}$ \\
\hline$A_{1}$ & 131 & $\begin{array}{c}13.04 \pm 0.87 \\
(12.0-16.9)\end{array}$ & $\begin{array}{c}38.68 \pm 2.43 \\
(34-50)\end{array}$ & $\begin{array}{c}4.56 \pm 0.37 \\
(3.9-6.1)\end{array}$ \\
\hline$A_{2}$ & 145 & $\begin{array}{c}14.36 \pm 1.04 \\
(13.0-17.3)\end{array}$ & $\begin{array}{c}42.23 \pm 2.94 \\
(36-49)\end{array}$ & $\begin{array}{c}4.94 \pm 0.39 \\
(4.2-6.1)\end{array}$ \\
\hline $\mathrm{B}_{1}$ & 135 & $\begin{array}{c}10.31 \pm 1.09 \\
(7.7-11.9)\end{array}$ & $\begin{array}{c}31.41 \pm 2.74 \\
(23-37)\end{array}$ & $\begin{array}{c}3.83 \pm 0.45 \\
(2.6-5.3)\end{array}$ \\
\hline $\mathrm{B}_{2}$ & 105 & $\begin{array}{c}11.00 \pm 1.27 \\
(8.1-12.9)\end{array}$ & $\begin{array}{c}33.30 \pm 3.66 \\
(25-44)\end{array}$ & $\begin{array}{c}3.92 \pm 0.52 \\
(3.1-6.1)\end{array}$ \\
\hline
\end{tabular}

Statistical analysis

\begin{tabular}{l|llc}
\hline & \multicolumn{3}{|c}{ p value } \\
\hline $\mathrm{A}_{1}$ vs $\mathrm{A}_{2}$ & $0.000 * * *$ & $0.000 * * *$ & $0.000 * * *$ \\
$\mathrm{~B}_{1}$ vs $\mathrm{B}_{2}$ & $0.000 * * *$ & $0.000 * * *$ & $0.138^{\mathrm{ns}}$ \\
$\mathrm{A}_{1}$ vs $\mathrm{B}_{1}$ & $0.000 * * *$ & $0.000 * * *$ & $0.000 * * *$ \\
$\mathrm{~A}_{2}$ vs $\mathrm{B}_{2}$ & $0.000 * * *$ & $0.000 * * *$ & $0.000 * * *$ \\
\hline
\end{tabular}

Results are expressed as Mean \pm SD. Statistical analysis was done by unpaired " $t$ " test. Figures in parentheses indicate ranges.

Control group

$$
\text { Group } B_{1}=\text { Anaemic female }
$$$$
\text { Study group }
$$$$
\text { Group } A_{1}=\text { Non anaemic female }
$$$$
\text { Group } A_{2}=\text { Non anaemic male }
$$

Group $B_{2}=$ Anaemic male

$\mathrm{n}=$ Number of subjects.

$\mathrm{ns}=$ Non significant. $* * *=$ Significant at $\mathrm{p}<0.001$.
Table III

Serum Ferritin (SF) level in microcytic hypochromic anaemic subjects $(n=68)$

\begin{tabular}{lcc}
\hline Groups & $\mathbf{n}$ & $\mathbf{S F}$ \\
& & $11.74 \pm 3.54$ \\
$\mathrm{~B}_{1}$ & 44 & $(6.07-23.45)$ \\
& & $13.07 \pm 4.77$ \\
$\mathrm{~B}_{2}$ & 24 & $(7.87-27.55)$ \\
\hline
\end{tabular}

Statistical analysis

\begin{tabular}{l|c}
\hline & p value \\
\hline $\mathbf{B}_{\mathbf{1}}$ vs $\mathbf{B}_{\mathbf{2}}$ & $0.193^{\text {ns }}$ \\
\hline
\end{tabular}


Results are expressed as Mean \pm SD. Statistical analysis was done by unpaired " $t$ " test. Figures in parentheses indicate ranges.

Group B = Anaemic subjects (Study group)

Group $B_{1}=$ Anaemic female

Group $B_{2}=$ Anaemic male

$\mathrm{n}=$ Number of subjects.

ns $=$ Non significant. $\quad * * *=$ Significant at $\mathrm{p}<0.001$.
Serum ferritin level was almost similar and showed no statistically significant difference between anaemic female and male (group $B_{1}$ and $B_{2}$ ) (Table III).

Serum ferritin level showed significant positive correlation with haemoglobin in anaemic female and male (group $B_{1}$ and $B_{2}$ ) (Figure 1).

Figure 1

Correlation of serum ferritin with $\mathrm{Hb}$ in microcytic hypochromic anaemic subjects $(n=68)$

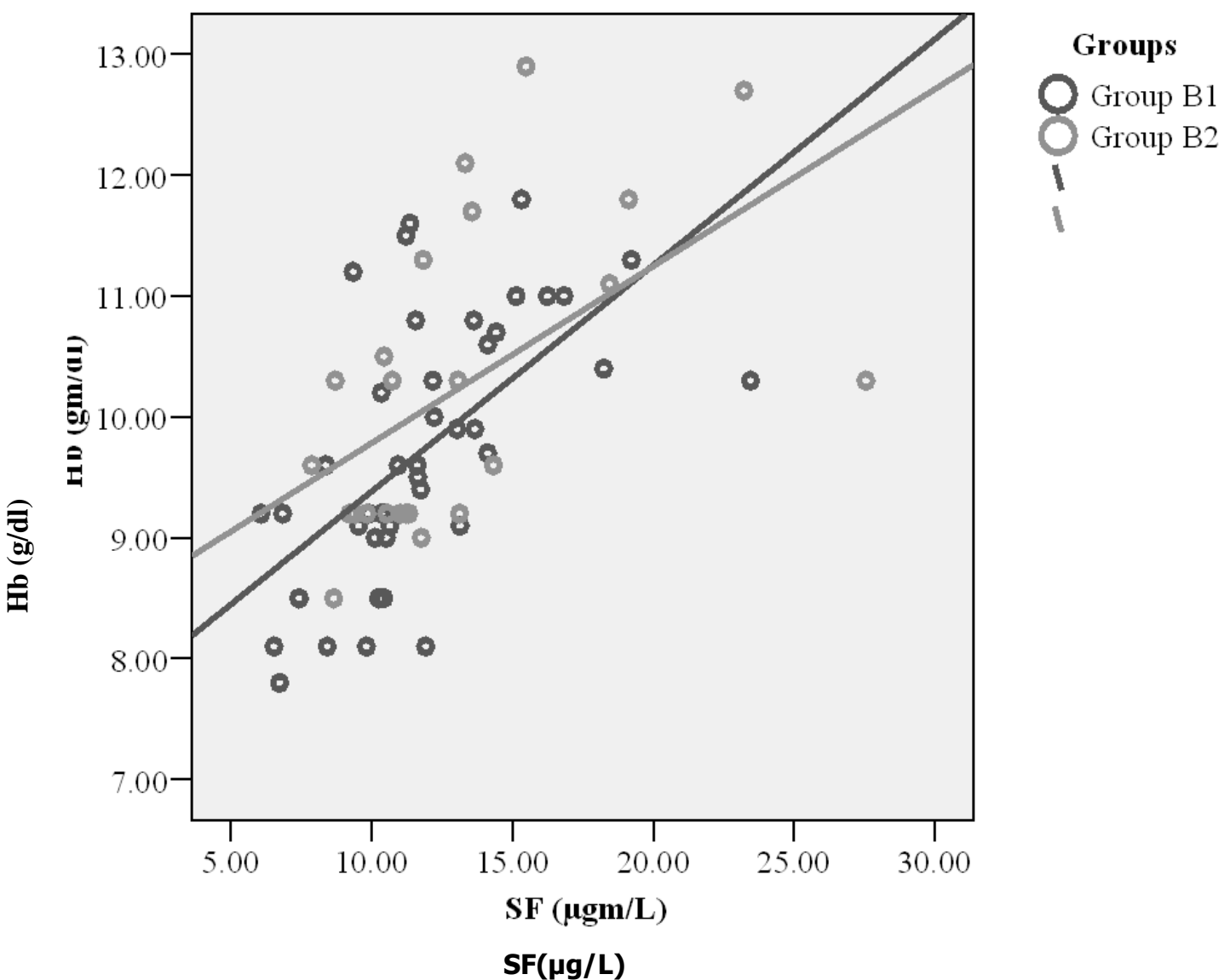

\section{Study group}

Group $B_{1}=$ Anaemic female $(n=44)$

Group $B_{2}=$ Anaemic male $(n=24)$

\section{DISCUSSION}

In this study, serum ferritin level was almost similar and showed no statistically significant difference of this value between anaemic female and anaemic male. This finding is in agreement with some researcher. $^{23}$ Again serum ferritin level showed significant positive correlation with $\mathrm{Hb}$ in both anaemic female and anaemic male. Similar observation is also made by other investigators. ${ }^{8,24}$
It is suggested that in this subcontinent peoples consume similar kind of diet. The staple diet is a mixture of cereals, pulses and vegetables. Bioavailability of iron from cereals and vegetables is low because of the presence of phytates, oxalates and tannate that react with iron to form insoluble compound and thus hampered iron absorption. ${ }^{25}$

The prevalence of anaemia was higher among female than male because of blood loss during the 
reproductive years. ${ }^{26}$ Decreased rate of erythropoisis ${ }^{27}$ and restricted diet may be associated predisposing factors for high prevalence of anaemia in females. ${ }^{28}$

The serum ferritin level is the most specific biochemical test that correlates with total body iron stores. ${ }^{19} \mathrm{~A}$ low serum ferritin level reflects depleted iron stores and hence is a precondition for iron deficiency. ${ }^{29}$ Again, it is suggested that the intake of dietary protein and iron are significant determinants of serum ferritin level. ${ }^{24}$ The prevalence of iron deficiency anaemia is high worldwide, especially in developing countries. ${ }^{30}$ It occurs may be due to chronic blood loss, dietary insufficiency, poor socio-economic condition and worm infestation. Moreover, the role of diet in the etiology of iron deficiency must be emphasized. Polyphenol containing beverages such as tea, coffee are known to reduce non haeme iron bioavailability by the formation of insoluble complexes. ${ }^{31}$ The adolescents are more vulnerable to iron deficiency may be due to increase iron requirements for rapid growth. ${ }^{32}$ Iron needs are highest in males during peak pubertal development because of a greater increase in blood volume, muscle mass and myoglobin. Iron deficiency anaemia was more prevalent in female than male due to their less consumption of iron containing food. ${ }^{33}$ In female after menarche, iron needs continue to remain high because of menstrual blood loss. ${ }^{34}$

In the present study, Microcytic hypochromic anaemia was present in some study subjects which is $32.6 \%$ among anaemic female and $22.9 \%$ among anaemic male, may be due to lower iron store as the measured value of serum ferritin and $\mathrm{Hb}$ are lower. These decreased levels most likely due to deficient intake of iron containing food. Menstrual loss of iron is an additional factor for iron deficiency anaemia in female.

\section{CONCLUSION}

From this study it concludes that serum ferritin is one of the most sensitive and accurate tests indicating iron status and thus microcytic hypochrmic anaemia. The study also shows that significant number of urban educated medical students are anaemic. So the study suggests the need for increasing awareness regarding diet, the ill effect to prevent it and the latent anaemia suggests the need of doing screening ferritin status among this young population group.

\section{Acknowledgement}

Authors of this study are thankful to the authority of Department Of Biochemistry, BSMMU for the cooperation regarding laboratory facility they provided. The authors are also thankful to all of study subject for their active and cordial cooperation to carry out the study.

\section{REFERENCES}

1. Viteri FE. The consequence of iron deficiency and anaemia in pregnancy on maternal health, the foetus and the infants. SCN News 1994; 11: 14-17.

2. Celkan T, Gur E, Can G, Yildiz I. Anaemic or not. Turk J Peditr 2003; 45(4): 329-333.

3. Ahmed F, Rahman A, Noor NA, Zaman A, Hughes R. Anaemia and vitamin A status among adolescent school boys in Dhaka city, Bangladesh. Public Health Nutr 2005; 9(3): 345-350.

4. Provan D. Mechanisms and management of iron deficiency anaemia. Br J Haematol 1999; 105(1): 119-126.

5. Beard LJ. Iron requirements in adolescent female. J Nutr 2000; 130(25-2): 440-442.

6. Gibson RS, Heath MLA, Ferguson LE. Risk of suboptimal iron and zinc nutritive among adolescent girls in Australia and New Zealand. Asia Pac J Clin Nutr 1992; 55: 955-958.

7. Brabin L \& Brabin JB .The cost of successful adolescent growth and development in girls in relation to iron and vitamin $A$ status. Am J Clin Nutr 1992 ; 55: 955- 958.

8. Ahmed F, Khan MR, Islam M, Kabin I, Fuchs GJ . Anaemia and iron deficiency among adolescent school girls in periurban Bangladeshi. Eur J Clin Nutr 2000 ; 54 : 678-683.

9. Edgerton VR, Gardner GW, Ohira Y, Gumawardena KA, Senawiratne B. Iron deficiency anaemia and its effect on work productivity and activity pattern. 1979; 2: 1546-1549.

10. Pollitt E, Hathirat $P$, Kotchabharkdi N, Missell L \& Valyesivi A Iron Deficiency and educational achievement in Thailand. Am J Clin Nutr 1989 ; 50 (Suppl): 687-696.

11. Hettiarachchi M, Liyanage C, Wickremasinghe R, Hilmers DC, Abrams SA. Prevalence and severity of micronutrient deficiency: a cross sectional study among adolescents in Sri Lanka. Asia Pac j Clin Nutrl 2006; 15(1): 56-63.

12. Ekpo AJ, Jimmy EO. Dietary and Haematological evaluation of adolescent female in Nigeria. Pak J Nut. 2006; 5(3): 275-281.

13. CDC. Recommendations to prevent and control iron deficiency in the United States. Morb Mortal wkly Rep 1998; 47 (RR-3): $1-29$.

14. Wharton BA. Iron deficiency in children: detection and prevention. $\mathrm{Br}$ J Haematol 1999; 106(2):.270-280.

15. Beard $\mathrm{U}$. Iron biology in immune function, muscle metabolism and neuronal Functioning. J Nutr 2001; 131(25-2): 568-579.

16. Bains K \& Mann SK. Serum ferritin as a measure of iron status in college girls. Indian J Med Sci 2000; 59(9) : 375-379.

17. Siimes MA, Addiego JE \& Dallman PR . Ferritin in serum: the diagnosis of iron deficiency and iron overload in infants and children. Blood 1974; 43: .581-590.

18. Abshire TC \& Reeves JD. Anaemia of acute inflammation in children. J Pediatr 1983; 103: 868-871.

19. INACG. Measurements of iron status: a report of the International Nutritional Anaemia Consultative Group', USA: INACG. 1985

20. WHO. Iron deficiency anaemia: assessment, prevention and control, World Health Organization. 2001. 
21. Foo LH, Khor GL, Tee $E$, Dhanaraj P. Determinants of iron status in Malaysian adolescents from a rural community. Int J Food Sci Nutr 2004; 55(6): 517-525.

22. Forman DT, Parkar SM. The measurement and interpretation of serum ferritin. Ann Clin Lab Sci 1996; 10: 345-50.

23. Alton I. Iron deficiency anameia in Stong J \& Story M (eds). Guide lines for adolescent Nutrition services. 2005; 101-108, < http://www.epi. umn.edu/let/pubs Adol_book shtm >

24. Sharma V, Sharma A. Health profile of pregnant adolescents among selected tribal population in Rajasthan. Ind J Adolesc Health 1992; 13: 696-699.

25. Shah BK, Gupta P. Anaemia in adolesent girls: A preliminary report form semi urban Nepal. Indian Pediatrics 2002; 39:11261130.

26. Basu S, Hazarika R \& Parmav V. Prevalence of anaemia among school going adolescents of Chandigarh. Indian pediatrics 2005; 42: 583-597.

27. Mukaya JE, Ddengu H, Sali F, O'Shea T, Crowther MA. and morphological types of anaemia and hook worm infestation in the medical emergency ward, Mulargo Hosptial,Uganda. S Afr Med J 2009; 99: 881-886.

28. Keele CA, Neil E, Joels N. Iron deficiency anaemia. Samson Wright's Applied Physiology. $13^{\text {th }}$ ed. Oxford University Press, New Delhi 1982; 42-43.

29. Ekpo AJ, Jimmy EO. Dietary and Haematological evaluation of adolescent female in Nigeria. Pak J Nut 2006; 5(3): 275-281.

30. Espino JM, Martinez $\mathrm{H}$, Greiner T. Iron deficiency anaemia in Tarahumara womem of reproductive age in Northern Mexico. Salud Publica Mex 2001; 43: .392-401.

31. Goyle A, Prokash S .Iron status of adolescent girls (10-15 years) attending a Government school in Jaipur City, Rajasthan, India. Mal J Nutr 2009; 15(1): 205-211.

32. Keskin $Y$, Moschonis $G$, Dimitrion M, Sur $H$, Kocaoglu B, Hayran $O$, Manios $Y$. Prevalence of iron deficiency among schoolchildren of different socio-economic status in urban Turkey. Eur J Clin Nutr 2004; 59: 64-71. 